\title{
Industrialização e desenvolvimento: uma análise do pensamento econômico brasileiro *
}

\author{
Marcelo Curado ${ }^{* *}$
}

\section{Resumo}

Este artigo recupera os elementos essenciais do debate sobre o papel do processo de industrialização para o desenvolvimento econômico brasileiro. O artigo analisa diversos momentos deste debate, desde suas origens até as recentes discussões sobre a desindustrialização. Argumenta-se que a evolução do tema influencia e é influenciada pelas condições históricas vigentes. Sua conclusão central é que o debate é profundamente marcado pelos diferentes pontos de partida teóricos e metodológicos adotados pela literatura

Palavras-chave: História do pensamento econômico; Economia brasileira; Industrialização; Estrutura produtiva e desenvolvimento; Heterodoxia x Ortodoxia.

\section{Abstract \\ Industrialization and development: an analysis of Brazilian economic thought}

This paper presents the most important elements of the debate on the role of industrialization for economic development in Brazil. The paper examines several stages of the debate, from its origins up to the recent discussions on deindustrialization. It is argued that the development of the theme influences and is influenced by prevailing historical conditions. Its central conclusion is that the debate is deeply marked by the different theoretical and methodological starting points adopted by the literature.

Keywords: History of economic thought, Brazilian economy, Industrialization, Productive structure and development, Heterodoxy vs. Orthodoxy.

JEL B10, B20.

\section{Introdução}

O debate sobre o papel da industrialização para o desenvolvimento econômico não é novo. Pelo contrário, trata-se de uma das mais antigas e controversas discussões presentes na literatura econômica brasileira. Há registros destas discussões desde o Império. Seu capítulo mais recente encontra-se na análise

* Trabalho recebido em 15 de julho de 2011 e aprovado em 21 de maio de 2012. O autor agradece os comentários dos dois pareceristas anônimos e aos professores Marco Antônio Ribas Cavalieri, Armando João Dalla Costa e Gustavo Pereira da Silva do grupo de pesquisa "Economia brasileira e Pensamento Econômico Brasileiro" pelos debates realizados que ajudaram na elaboração do artigo. Os erros remanecentes são de responsabilidade exclusiva do autor.

** Professor do Programa de Pós-Graduação em Desenvolvimento Econômico da Universidade Federal do Paraná (UFPR). Pesquisador do Programa Cátedras para o Desenvolvimento do Instituto de Pesquisa Econômica Aplicada (Ipea) (2011/2012). E-mail: mlcurado@gmail.com. 
sobre a ocorrência de um processo de "desindustrialização" e seus efeitos para o desenvolvimento de longo prazo do país.

O objetivo deste artigo é recuperar os elementos essenciais do debate sobre o papel do processo de industrialização para o desenvolvimento econômico brasileiro. Ao longo das discussões, ainda que de forma breve, procura-se também demonstrar como a "evolução" do tema influencia e é influenciada pelas condições históricas vigentes. Longe de promover uma análise detalhada da evolução do pensamento econômico nacional, como realizada, por exemplo, por Bielschowsky (1988) e Mantega (1984), o artigo pretende responder exclusivamente a uma indagação: Quais os fundamentos para a controvérsia existente sobre o papel da industrialização no desenvolvimento brasileiro?

$\mathrm{O}$ artigo analisa alguns momentos específicos desta discussão. Foram selecionados cinco momentos para análise. O primeiro aborda desde as origens das discussões até a sua "difusão" nos primeiros anos da República. É interessante notar como alguns dos elementos presentes nas discussões contemporâneas já se encontravam presentes desde sua origem. O segundo momento escolhido analisa $\mathrm{o}$ debate realizado entre o industrial Roberto Simonsen e o economista liberal Eugênio Gudin na década de quarenta do século XX. Este foi um debate importante, sobretudo se levarmos em consideração o momento histórico em que foi realizado.

O desenvolvimento e a difusão das teses originais da Cepal no final da década de quarenta e início dos anos cinqüenta do século passado é o terceiro momento escolhido para investigação, tendo em vista que serviu como ponto de partida para todo um conjunto de reflexões sobre o tema que perduraram durante um longo período. É também nesta fase que o mito da industrialização como mecanismo de promoção do desenvolvimento atingiu o seu apogeu.

A década de noventa, tendo em vista as profundas transformações ocorridas, em que se destacam o ínicio da abertura comercial, o processo de privatização e a estabilidade de preços, foi profícua para o debate sobre o papel da estrutura produtiva no desenvolvimento, elemento que justifica a escolha deste período. Por fim, o artigo explora as recentes discussões sobre "desindustrialização" e a escolha e pertinência do uso de instrumentos de política industrial.

\section{Estrutura produtiva, industrialização e desenvolvimento: as origens do debate}

Luz (1975) argumenta que o período do Império foi marcado pelo consenso sobre a vocação agrícola da economia brasileira. Os expoentes do debate 
da época, o Visconde de Cairu (José Maria da Silva Lisboa) e Tavares Bastos, eram ardorosos defensores do liberalismo econômico. Argumentavam que o Brasil deveria especializar-se nas atividades agrícolas e na extração mineral, dadas as vantagens comparativas existentes, particularmente a abundância e a qualidade das terras cultiváveis. A especialização na produção agrícola e o comércio com países produtores de manufaturas seria peça central para a ampliação da prosperidade econômica do Brasil e de seus parceiros comerciais.

Tavares Bastos, por exemplo, defendia explicitamente que o Brasil não teria uma vocação industrial, "não devendo lutar contra a sua própria natureza". Na realidade, o desenvolvimento de atividades industriais geraria diversos problemas para a economia, com destaque para o encarecimento dos alimentos e o agravamento do problema de escassez de mão-de-obra. Luz (1975) sintetiza o pensamento de Tavares Bastos, da seguinte forma:

Invocando, a seguir, a Autoridade do Visconde de Cairu e, trazendo a baila os velhos argumentos fisiocratas, opinava que o Brasil deveria se restringir à agricultura e à indústria extrativa por serem, no país, as mais racionais e lucrativas e, acreditando serem mais felizes as populações rurais do que a urbana, aconselhava ser mais desejável promover a democracia rural do que aumentar a população operária das cidades (Luz, 1978, p. 54).

Em síntese, em sua origem a discussão sobre o papel da estrutura produtiva no desenvolvimento foi marcada pela visão - comum ao pensamento econômico da época - de que os países deveriam especializar-se em função das condições impostas pela natureza, o que no caso brasileiro implicava a defesa de um padrão de especialização concentrado na produção agrícola e na exploração mineral.

Este cenário é, em alguma medida, alterado com a Proclamação da República, especialmente por ocasião da elaboração da Constituinte Republicana. Neste momento, a ênfase nas atividades primário-exportadoras e o frágil desenvolvimento das atividades industriais passaram a ser questionados. Assim, ainda que a influência do pensamento liberal inglês, especialmente a visão ricardiana consolidada na teoria das vantagens comparativas, mantenha-se como predominante nos debates, pode-se notar o surgimento, ainda que marginal, da defesa de um processo de industrialização" como forma de "superar o caráter ainda colonial de nossa economia". Fonseca (2000) apresenta evidências deste debate:

Amaro Cavalcanti, senador na Constituinte e ministro várias vezes, atribuía a crise de 1892 ao fato de se depender de importações de produtos estrangeiros, enfatizando que nenhum povo poderia ser "grande, respeitado e feliz" sem a “condição essencial de possuir sua riqueza própria". As crises de balanço de

(1) Destacam-se como "defensores da indústria" no período: Amaro Cavalcanti, Aristides de Queirós, Alcindo Guanabara, Serzedelo Correa e Felisbelo Freire, de acordo com Fonseca (2004) 
pagamentos e de escassez de divisas eram interpretadas como decorrentes da demasiada dependência de importados do estrangeiro (uma causa "estrutural", e não fenômeno decorrente da política econômica instrumental de curto prazo). Já o deputado Aristides de Queirós, em 1895, imputava aos governos da monarquia a "progressão tamanha de nossa importação" e asseverava: "Entendo que a República, a geração atual está no dever, tem obrigação de iniciar uma reação contra este estado de coisas, inaugurando o período de uma política financeira francamente protecionista. É preciso proteger agora e principalmente a indústria superior; e eu chamo de indústria superior a indústria manufatureira. Os nossos produtos são exclusivamente coloniais, por isto mesmo que somos um país exclusivamente agrícola. E um país exclusivamente agrícola, que apresenta no mercado internacional somente produtos coloniais, não passa das condições de inferioridade econômica de uma colônia (Fonseca, 2000, p. 4).

Ressalta-se a presença de dois argumentos centrais na raiz da defesa da expansão das atividades industriais. $\mathrm{O}$ primeiro diz respeito à associação entre a concentração da produção nacional em produtos agrícolas e à "inferioridade econômica de uma colônia". Ainda que de forma não sistematizada, poder-se-ia afirmar que já existia neste momento um primeiro esboço da relação entre o grau de desenvolvimento econômico e as características da estrutura produtiva. A divisão internacional do trabalho já estava clara. Países produtores e exportadores exclusivamente de produtos agrícolas, ainda que politicamente independentes, não passariam de uma perspectiva econômica das "condições de inferioridade de uma colônia". A industrialização se constituiria, nesta concepção, numa peça chave para a superação deste caráter colonial. Outro argumento já presente nestas discussões diz respeito aos impactos sobre o Balanço de Pagamentos do padrão de especialização concentrado na produção agrícola e nas atividades extrativas minerais. A excessiva dependência da compra de bens industriais do exterior, ao pressionar a conta de importações, ampliava a dependência externa da economia.

A crítica à teoria econômica convencional constituía-se também num elo de união dos defensores da indústria. Em seu lugar, propunham como guia para a formulação de políticas a observação dos processos históricos concretos de desenvolvimento, ou seja, defendiam uma visão mais vinculada com a experiência histórica, com a vida real. "Este pragmatismo pode ser facilmente detectado por quem analisa o discurso dos defensores da industrialização... Isto se evidencia quando eles reivindicam a si mesmos coerência com a prática, com a vida real, denunciando os partidários do livre comércio e da lei das vantagens comparativas como "teóricos", voltados a teses desvinculadas da experiência" (Fonseca, 2004, p. 233).

Embora não seja o foco central deste trabalho, é interessante notar, ainda que brevemente, como as teses industrialistas encontravam-se inseridas no debate 
do período, influenciando e sendo influenciadas por outras correntes do pensamento. A primeira e mais antiga destas correntes era o nacionalismo. A defesa dos interesses nacionais remontava o período colonial, com destaque para a crítica ao exclusivismo metropolitano.

Um aspecto importante, tendo em vista o objetivo deste trabalho, é denotar que embora parte dos nacionalistas defendesse o desenvolvimento da indústria, não se deve restringir o nacionalismo a este caso. Destaca-se a existência de um importante grupo "nacionalista agrário" que via na expansão da agricultura nacional a fonte prioritária de desenvolvimento da nação. No entanto, os "defensores da indústria" argumentavam que a expansão das atividades industriais constituía-se num elemento chave para a defesa dos interesses nacionais. Em suma, "embora nem todo nacionalismo fosse industrializante, a defesa da indústria tinha no nacionalismo um de seus melhores argumentos... os defensores da indústria recorreriam, de aí em diante, ao nacionalismo como ponto importante de seu discurso" (Fonseca, 2004, p. 230).

Os papelistas constituíam outra corrente importante do debate da última década do século XIX. O ponto de partida desta corrente encontrava-se na crítica à utilização do padrão ouro como regra para definir o volume de emissão de moeda. Propunham que a emissão monetária deveria ser desvinculada do volume das reservas metálicas e que a oferta de moeda deveria adequar-se às necessidades dos negócios ${ }^{2}$. A relação entre o papelismo e os defensores da indústria deve ser vista com cautela. Cardoso (1975), por exemplo, defende uma associação direta entre a defesa da indústria e o papelismo. Esta simplificação é, no entanto, equivocada. Embora alguns "defensores da indústria" fossem adeptos das teses papelistas, este comportamento não pode ser generalizado ${ }^{3}$.

Por fim, é importante destacar, de uma perspectiva mais ampla, a influência do pensamento positivista no período. A visão de que um dos principais objetivos de uma sociedade é a busca do progresso econômico e que é função do Estado ajudar na sua promoção influenciaram profundamente o debate, com especial importância na formação do pensamento militar no governo republicano. Vale lembrar que Benjamin Constant, destacado defensor e difusor do positivismo no país, foi Ministro da Guerra de Deodoro da Fonseca.

De acordo com Fonseca (2004), o positivismo foi crucial para a formação do pensamento desenvolvimentista brasileiro - em contraposição à visão liberal, pois:

(2) Rui Barbosa foi um de seus principais expoentes

(3) Fonseca (2004) apresenta como exemplo o caso de Serzedelo Correa, nacionalista e defensor da indústria, mas fortemente contrário às teses papelistas. 
Pragmaticamente ampliava a agenda do Estado, aceitando sua participação quando houvesse necessidade social... e por acenar um futuro a ser buscado, com a história correndo a seu favor - daí progressista -, ao entendê-la como um processo evolutivo e conclamando os governantes para sua construção. Assim, mais que com idéias específicas, como o nacionalismo e a defesa da indústria, o positivismo contribuiu para algo mais sofisticado e definidor, que é uma mudança de postura dos governantes, pois supunha uma visão globalizante do processo histórico, a qual the dava um sentido (Fonseca, 2004, p. 18).

Em síntese, o surgimento das teses industrialistas ocorreu num contexto de grande efervescência de ideias e desenvolvimento de correntes de pensamento. Além do pensamento liberal inglês, dominante nos temas econômicos, destacavamse na construção do debate, de acordo com Fonseca (2004), o nacionalismo, o papelismo e, numa perspectiva mais ampla e não estritamente econômica, o positivismo. Sem dúvida, as teses industrialistas foram influenciadas por este contexto, devendo-se, no entanto, evitar associações diretas e simplificadoras que não levam em consideração aspectos relevantes da discussão.

A evolução deste debate foi marcada pelas alterações concretamente processadas no cenário econômico e político do país. Não é mera coincidência que o surgimento de teses industrialistas tenha ocorrido após a Proclamação da República, período em que o país iniciava os primeiros passos na direção da constituição de uma nação. Este é o contexto histórico em que ganha força, ainda que marginalmente, a visão de que a expansão das atividades industriais seria essencial para reduzir o caráter ainda "colonial" de nossa economia.

Além deste aspecto mais geral, elementos mais pontuais devem ser incorporados para entender o surgimento das teses industrialistas. Do ponto de vista da condução da política econômica, o início da República foi marcado pela administração do papelista Rui Barbosa. Uma das principais medidas de política econômica de sua gestão foi a instituição da Lei Bancária em 1890 que, de acordo com a visão convencional do período, foi uma das principais determinantes da crise do Encilhamento ${ }^{4}$. Do ponto de vista da evolução da estrutura produtiva é interessante notar que se observou nos primeiros anos da República uma expansão das atividades industriais, fenômeno associado à política expansionista engendrada por Rui Barbosa.

Vale lembrar que o período foi igualmente marcado pela aceleração da inflação. A leitura mais ortodoxa creditava à política monetária expansionista e ao surgimento de "indústrias artificiais", mantidas sob forte proteção tarifária, a

(4) A lei promoveu uma significativa expansão monetária, elemento central para a crise do Encilhamento. De acordo com Franco (1989, p. 21): “A lei estabelecia emissões bancárias a serem feitas sobre um lastro constituído por títulos da dívida pública. As emissões seriam inconversíveis, e o total autorizado era de 450 mil contos, mais do dobro do papel moeda em circulação em janeiro.” 
responsabilidade pela expansão inflacionária. A visão mais convencional defendia, portanto, que a inflação brasileira era o resultado da expansão monetária conduzida por Rui Barbosa e do surgimento de "indústrias artificiais". Nesta concepção, o país deveria privilegiar o desenvolvimento de "indústrias naturais", associadas ao setor agrário. É neste contexto que surgem os "defensores da indústria", com destaque para Amaro Cavalcanti e Aristides de Queirós, para os quais a crise do Encilhamento e a aceleração da inflação decorriam do ainda frágil desenvolvimento dos setores industriais e da elevada dependência externa da economia brasileira. É salutar lembrar que o início da República foi marcado também pelo agravamento da situação externa. A situação tornou-se praticamente insustentável em 1898, ano em que o governo brasileiro foi praticamente obrigado a formalizar o primeiro "acordo de consolidação" (funding loan) com a Casa Rothschild 5 .

Apesar de seu desenvolvimento, as discussões sobre o papel da industrialização para o desenvolvimento brasileiro podem ser classificadas como marginais, tanto da perspectiva acadêmica, quanto de sua influência na execução de políticas econômicas voltadas ao desenvolvimento da indústria. Furtado (1968), entre outros, defende que as políticas econômicas instituídas pelo governo até a década de trinta serviam aos interesses econômicos da burguesia cafeeira.

É importante notar, tal como argumentado por Perissinotto (1993, 1994), que os interesses cafeeiros eram significativamente heterogêneos. Neste sentido, é mais preciso afirmar que "...na forma final assumida por essas políticas, o grande capital cafeeiro conseguiu, aliado ao capital estrangeiro, fazer com que seus interesses fundamentais fossem atendidos de forma prioritária, ao passo que a lavoura cafeeira teve seus interesses fundamentais - em especial o monopólio oficial do comércio do café e uma política creditícia eficaz - sistematicamente lesados" (Perissinotto, 1993, p. 168). Não obstante, o elemento central a ser destacado, tendo em vista os objetivos deste trabalho, é que até a década de trinta, os interesses do setor industrial ocuparam um papel marginal na agenda dos formuladores de política econômica.

Em síntese, a defesa da expansão das atividades industriais ganha força a partir da Proclamação da República, tendo em vista que: 1) O desenvolvimento destas atividades, originalmente realizadas nas antigas metrópoles, permitiria a superação do caráter colonial da economia; 2) A redução das importações de produtos industriais traria impactos positivos para as contas externas e 3) A observação histórica do desenvolvimento das nações deixava evidente, ao contrário das proposições vinculadas à teoria econômica convencional, a importância da

(5) Para uma discussão sobre a situação externa e os sucessivos funding loans acordados pelo Brasil com os credores internacionais, recomenda-se a leitura de Abreu (2002) 
expansão da indústria para o desenvolvimento. O surgimento de um pensamento industrialista foi fortemente influenciado pelo contexto histórico e pelos debates existentes na época, com destaque para o pensamento nacionalista e a influência do pensamento positivista. Ainda assim, e este é o ponto central que deve ser destacado, se trata de um desenvolvimento inicial, um esboço dos argumentos que serão elaborados em sua plenitude somente no início dos anos cinqüenta do século $\mathrm{XX}$.

\section{0 debate entre Roberto Simonsen e Eugênio Gudin}

$\mathrm{Na}$ década de quarenta do século $\mathrm{XX}$, intensos debates sobre o papel da estrutura produtiva para o desenvolvimento econômico foram realizados. Em particular, merece destaque a discussão travada entre o industrial Roberto Simonsen e o economista liberal Eugênio Gudin.

Em grande medida, estas discussões refletiam a evolução das atividades industriais presentes desde o início da década de trinta. A década foi marcada pelo intenso desenvolvimento das atividades industriais no Brasil. Além do ritmo acelerado de crescimento das atividades industriais - entre 1933 e 1939, o setor industrial cresceu a uma taxa média de 11,2\% aa - observou-se também um importante processo de diversificação das atividades produtivas. De acordo com Possas (1983), em 1920, cerca de 75\% da produção industrial era derivada do setor de bens salário, com participação significativa dos ramos têxteis, bebidas e produtos alimentares, enquanto o setor de bens de produção respondia por apenas $7 \%$ do produto industrial. Já em 1939, a produção dos setores de bens intermediários e dos bens de capital saltou, respectivamente, para $22 \%$ e $8,8 \%$ do produto industrial.

O modelo de substituição de importações do período caracterizou-se, entre outros elementos, pelo elevado grau de fechamento da economia doméstica à concorrência externa e pela presença marcante dos investimentos do Estado, sobretudo nos setores que apresentavam barreiras às entradas (financeiras e tecnológicas) praticamente intransponíveis ao capital privado nacional e que não interessavam - em função da baixa rentabilidade e dos elevados prazos de maturação - ao capital privado estrangeiro.

Outra característica marcante desta fase da industrialização brasileira encontrava-se em sua elevada dependência das importações, sobretudo de bens de capital e insumos industriais. Não é sem motivos que após a eclosão da II Guerra mundial, o ritmo de crescimento das atividades industriais foi reduzido. Entre 1939 e 1945 a taxa de crescimento médio anual destas atividades foi - de acordo com Villela e Suzigan (1975) - de 5,4\%, bem inferior ao patamar observado entre 1933 e 1939. 
$\mathrm{Na}$ visão de Simonsen, o desenvolvimento das atividades industriais constituía-se no elemento central de uma estratégia para a superação do subdesenvolvimento. Em alguma medida, pode-se considerar Simonsen como um herdeiro do pensamento nacionalista-industrialista do século XIX. Para o autor, há uma forte correlação entre o desenvolvimento das atividades industriais no país e a constituição de uma "estrutura econômica e social forte e estável". De acordo com o autor:

Impõe-se, assim, a planificação da economia brasileira em moldes capazes de proporcionar os meios adequados para satisfazer as necessidades essenciais de nossas populações, e o prover o país de uma estrutura econômica e social forte e estável... A parte nucleal de um programa dessa natureza... tem que ser constituída pela industrialização (Simonsen [1945]. In: Simonsen; Gudin, 2010, p. 14, grifo meu).

A passagem acima permite - além de verificar a associação entre industrialização e desenvolvimento - notar outro elemento importante da visão do autor. Para Simonsen, o desenvolvimento das atividades industriais não ocorreria como fruto de um processo natural de funcionamento das forças de mercado. Pelo contrário, o desenvolvimento destas atividades seria fruto de um esforço coordenado de planificação com ampliação do papel do Estado na economia. $\mathrm{O}$ frágil desenvolvimento do capital privado nacional e as barreiras existentes para sua atuação em diversas atividades econômicas constituíam-se nos elementos centrais do argumento de Simonsen de defesa da intervenção estatal.

... a renda nacional está praticamente estacionária, não existindo possibilidade, com a simples iniciativa privada, de fazê-la crescer, com rapidez ao nível indispensável para assegurar um justo equilíbrio econômico e social... Essa insuficiência, em vários setores da iniciativa privada, tem sido reconhecida pelo governo federal que direta ou indiretamente... tem promovido a fixação de importantes atividades no país (Simonsen [1945]. In: Simonsen; Gudin, 2010, p. 47)

Em lado oposto no debate, encontra-se o economista Eugênio Gudin. Fiel representante da tradição liberal, o autor atacou de forma veemente a existência de uma relação direta, tal como proposto por Simonsen, entre industrialização e desenvolvimento. De acordo com Gudin:

Um dos argumentos mais correntes a favor de nossa industrialização é o de que os países industrializados são ricos e os países de economia agrícola ou extrativa são pobres. Como princípio, não é verdadeiro... a economia agrícola pode formar um país muito rico e de alto padrão de vida. Para nós brasileiros, basta que olhemos para a Argentina... E se continuarmos a expandir indústrias que só podem viver sob a proteção das pesadas tarifas aduaneiras e do câmbio cadente, continuaremos a ser um 
país de pobreza, ao lado do rico país que é a Argentina (Simonsen [1945]. In: Simonsen; Gudin, 2010, p. 105)

Gudin não argumenta apenas que não há relação entre industrialização e desenvolvimento. $\mathrm{O}$ autor vai além, argumentando que o desenvolvimento artificial das atividades industriais, promovido através de forte proteção tarifária e com intervenção direta do Estado acarretaria na manutenção do subdesenvolvimento. Para o autor "tudo está na produtividade" e o essencial para o desenvolvimento econômico era "aumentar nossa produtividade agrícola, em vez de menosprezar a única atividade econômica em que demonstramos capacidade para produzir vantajosamente" (Simonsen; Gudin, 2010, p. 15). A influência da teoria das vantagens comparativas não é algo subliminar na obra de Gudin. O relato apresentado pelo autor para a Comissão de Planejamento Econômico (CPE) em 1945 traz uma seção em que se defende explicitamente a teoria de Ricardo.

É evidente que os debates processados em meados dos anos quarenta entre Roberto Simonsen e Eugênio Gudin foram profundamente influenciados pelo ambiente econômico e político da época. A partir de 1937, com a instituição do Estado Novo, Vargas assume deliberadamente o projeto industrializante, baseado na proteção à indústria nacional e na realização de investimentos públicos. A criação da Companhia Siderúrgica Nacional (CSN) em 1941 é um símbolo deste projeto.

Na realidade, não há como desvincular os argumentos dos autores das condições históricas vigentes. Basta lembrar que os elementos centrais das discussões nasceram do relatório apresentado por Simonsen para o Conselho Nacional de Política Industrial e Comercial em agosto de $1944^{6}$. Por sua vez, a resposta de Gudin a Simonsen foi apresentada em seu relato a CPE em 1945. Um exemplo evidente da importância das condições concretas da economia local e mundial para o debate encontra-se na crítica de Gudin ao esforço de planejamento estatal, já que para o autor: “A mística da planificação é, portanto, uma derivada genética da experiência fracassada e abandonada do New Deal americano, das ditaduras italiana e alemã, que levaram o mundo à catástrofe, e dos planos quinquenais da Rússia, que nenhuma aplicação pode ter em outros países" (Simonsen [1945]. In: Simonsen; Gudin, 2010, p. 74)

Em síntese, o debate realizado por Eugênio Gudin e Roberto Simonsen na década de quarenta traz à tona uma série de elementos há muito tempo discutidos. Enquanto o primeiro recupera e reafirma as teses neoliberais, o segundo pode ser considerado, em grande medida, um herdeiro do pensamento industrialistanacionalista presente no país desde a Proclamação da República.

(6) Publicado em 1945. 


\section{O pensamento cepalino original, o "desenvolvimentismo" e seus desdobramentos}

A influência do pensamento da Cepal na formação do pensamento econômico brasileiro é fato amplamente reconhecido pela literatura ${ }^{7}$. Prebisch (1949) e o documento elaborado pela Cepal em 1951 são marcos da construção do que se convencionou chamar de "pensamento cepalino original" ou simplesmente "velha Cepal". Em última análise, pode-se afirmar que estes trabalhos consolidaram o que posteriormente denominou-se "desenvolvimentismo" .

Do ponto de vista da evolução das ideias é importante destacar, como observou Fonseca (2000), que boa parte dos argumentos desenvolvidos pelo pensamento cepalino original e sua defesa do processo de industrialização na América Latina já se encontravam presentes há muito tempo no debate. No caso brasileiro, tal como apresentado nas seções anteriores, a discussão sobre a importância da indústria remonta a Proclamação da República. Esta consideração não deve, no entanto, ofuscar os avanços decorrentes da construção cepalina original, particularmente do trabalho de Prebisch (1949), que efetivamente elaborou uma abordagem teórica consistente de defesa da industrialização como promotora do desenvolvimento.

O ponto de partida é a organização da divisão internacional do trabalho em dois blocos: o centro (formado pelo conjunto de economias industrializadas) e a periferia (composto pelos países que participavam desta divisão internacional do trabalho como fornecedores de insumos, matérias-primas e produtos agrícolas).

O argumento da "velha Cepal" é que esta divisão internacional do trabalho se constituía no principal responsável pelo subdesenvolvimento das regiões periféricas. As relações comerciais entre o centro e a periferia instituíam este vínculo entre as características da estrutura produtiva e o grau de desenvolvimento econômico. Prebisch (1949) entende que a divisão internacional do trabalho entre centro e periferia promoveria ao longo do tempo uma "deterioração dos termos de troca" entre as regiões, com evidente desvantagem para a periferia.

O ponto de partida do argumento é a hipótese, bastante plausível para o período, de que os preços dos produtos industrializados apresentavam forte rigidez à baixa. A estrutura de mercado oligopolizada e o poder de barganha dos sindicatos organizados nos países centrais impediriam quedas bruscas nos preços destes produtos, mesmo em períodos de retração da demanda mundial. Por sua vez, a

(7) Para uma discussão profunda sobre a influência cepalina no pensamento brasileiro, recomenda-se a leitura de Bielschowsky (1988).

(8) Adota-se aqui o conceito de desenvolvimentismo elaborado por Bielschowsky (1988, p. 33) como o "projeto de superação do subdesenvolvimento através da industrialização integral, por meio de planejamento, e decidido apoio do Estado". 
oferta de produtos básicos se dava numa estrutura de mercado do tipo competitiva, o que, em última análise, explicava a maior flutuação destes preços, sobretudo em períodos de retração da demanda mundial.

No longo prazo, esta deterioração dos termos de troca entre os países periféricos e centrais obrigava os primeiros a exportar um quantum maior de produtos básicos para obter a mesma quantidade de bens industrializados. Isto, no entanto, não era possível já que a elasticidade-renda da demanda dos produtos básicos era menor do que a elasticidade-renda das exportações dos produtos industrializados.

Neste modelo, os ciclos de expansão/crise das economias periféricas encontram-se muito bem definidos. Períodos de crescimento do nível de atividade geravam forte crescimento na demanda por bens industrializados (importados dos países centrais). No entanto, este crescimento na demanda por importações não poderia ser financiado pela entrada de divisas advindas das exportações de produtos básicos, dada a baixa elasticidade-renda destes últimos. Uma solução de curto prazo seria financiar o excesso de gastos com o exterior através do endividamento externo, solução que no longo prazo demonstrava-se insustentável, tendo em vista as pressões que os serviços da dívida externa (juros e amortizações) geravam sobre o Balanço de Pagamentos e que as condições de liquidez internacional para os países emergentes alteravam-se constantemente.

Em síntese, dada a divisão internacional do trabalho, os períodos de expansão das economias periféricas gerariam desequilíbrios comerciais insustentáveis no longo prazo. Neste contexto, restava aos formuladores de política a utilização de instrumentos de retração da atividade que encerravam o ciclo de crescimento. A industrialização seria a forma de superar a restrição externa imposta ao crescimento dos países periféricos.

A superação do subdesenvolvimento se daria, portanto, a partir do processo de industrialização e da redefinição das relações comerciais entre centro e periferia. Promover a industrialização, na visão da "velha Cepal", era sinônimo de promover o desenvolvimento. Estrutura produtiva e desenvolvimento caminhavam, portanto, lado a lado.

Além de permitir a superação da restrição externa ao desenvolvimento, é importante notar que a "velha Cepal" já apresentava em seus trabalhos a concepção de que os encadeamentos para frente e para trás da indústria seriam muito superiores aos verificados nas atividades primárias ${ }^{9}$.

(9) “A indústria traz em si um elemento dinâmico que a produção primária não possui em grau comparável. A produção primária, como seu nome indica, abrange as primeiras etapas do processo produtivo, enquanto a indústria compreende as etapas subseqüentes. Devido a esta posição relativa de ambas atividades, o 
O pensamento cepalino teve grande influência no Brasil, tanto no plano acadêmico, quanto no âmbito das decisões políticas. A importância da Comissão Cepal/BNDE no desenvolvimento dos grandes projetos executados na segunda metade da década de cinqüienta no âmbito do Plano de Metas é bastante conhecida, da mesma forma que a influência cepalina nos meios acadêmicos brasileiros neste período e nas décadas subseqüentes.

A importância política e acadêmica do pensamento cepalino e a difusão de suas teses "desenvolvimentistas" ocorreram num momento histórico específico, após a II Guerra Mundial e o início da guerra fria. Na leitura de Fiori (2000) a formação de uma "coalização desenvolvimentista" na América Latina encontra-se vinculada às condições vigentes na economia mundial e, particularmente, às alterações na política externa norte-americana após 1947 e sua preocupação com a expansão do socialismo. O projeto desenvolvimentista, na perspectiva do autor, é a resposta capitalista "tolerada pelos liberais" para fazer frente à expansão do projeto socialista.

Logo depois da inflexão da política externa norte-americana, em 1947, e sobretudo depois da vitória da Revolução Chinesa e da Guerra da Coréia, o desenvolvimentismo transformou-se na resposta capitalista - tolerada pelos liberais - ao projeto socialista para os países subdesenvolvidos. Quase poderse-ia dizer, parafraseando John Williamson algumas décadas depois, ter sido ali que se constituiu o primeiro Consenso de Washington - e ele era desenvolvimentista - apesar de a ideologia da estabilização do Fundo Monetário Internacional já ser inquestionável... Se olharmos esta mesma inflexão a partir do Brasil perceberemos que o desenvolvimentismo brasileiro também nasceu de forma pragmática e foi capaz de aglutinar quase todos os segmentos das classes dominantes e suas elites. Normalmente, e quase naturalmente, são os setores mais dinâmicos, ou aqueles representados pelos setores industriais de ponta, que são colocados sob à luz dos refletores dos estudos de sociólogos e politólogos. No caso brasileiro, essa elite concentrouse em São Paulo em torno do complexo metal mecânico que então surgia, tendo à frente a indústria automobilística. Essa era a fração mais moderna do capitalismo brasileiro e nasceu associada ao capital multinacional. Entretanto, outras frações não menos importantes, mas talvez menos modernas do ponto de vista econômico e político, também encontraram o seu espaço dentro da coalizão desenvolvimentista (Fiori, 2000, p. 3).

Em suma, não é exagero afirmar que a construção cepalina original consolidou e difundiu na América Latina a visão de que o processo de industrialização da região seria uma peça essencial na superação do subdesenvolvimento. No entanto, é interessante notar como, apesar da manutenção

aumento da atividade industrial fomenta a atividade primária; esta, ao contrário, não possui o poder de estimulara atividade industrial" (Cepal, 1949, p. 49). 
de algumas das peças chaves desta construção, o pensamento econômico brasileiro acabou paulatinamente afastando-se desta associação direta entre desenvolvimento e industrialização proposta pela "velha Cepal". A leitura de alguns autores importantes sobre o tema da industrialização, muitos dos quais contribuíram para a construção original da Cepal, permite verificar este processo.

Celso Furtado, por exemplo, desempenhou papel relevante na construção e na divulgação das ideias cepalinas nos anos cinqüenta, ainda que desde o início fossem observadas diferenças importantes entre a sua obra e a visão cepalina original, em diversos aspectos ${ }^{10}$. A defesa do projeto industrializante encontra-se em Furtado, sobretudo no livro: "Desenvolvimento e Subdesenvolvimento", publicado em 1961, diretamente vinculada ao conceito de desenvolvimento econômico presente neste trabalho. "O desenvolvimento econômico (...) consiste na introdução de novas combinações de fatores de produção que tendem a aumentar a produtividade do trabalho" (Furtado, 1961, p. 91). Os setores dinâmicos, capazes de promover este incremento da produtividade do trabalho, encontravam-se vinculados às atividades industriais, justificando-se, portanto, o projeto industrializante ${ }^{11}$.

Além destes elementos, presentes em Furtado (1961), é possível encontrar em "Formação Econômica do Brasil", publicado originalmente em 1959, pelo menos dois argumentos adicionais pró-industrialização. O primeiro diz respeito ao papel do desenvolvimento das atividades industriais na contenção do processo inflacionário. Para Furtado, a inflação brasileira no início dos anos cinquienta era o resultado do crescimento acelerado da demanda, fruto da expansão da renda monetária do setor exportador, num cenário de relativa inelasticidade da oferta de manufaturas. $\mathrm{O}$ crescimento da desta oferta, associado a industrialização, constituía-se numa peça importante para promover o ajuste entre oferta e demanda de bens manufaturados, necessário para a contenção da inflação.

Muito mais importante, no entanto, era o impacto do processo de industrialização em reduzir a importância do cenário externo para a realização dos

(10) De acordo com Bielschowsky (1988, p. 166): "Na fase de lançamento das teses estruturalistas, a ênfase dos textos de Prebisch era que a industrialização representava a solução a que deveriam dedicar-se os países latino-americanos para superar o subdesenvolvimento. Esses textos têm o sentido geral de defesa de um amplo projeto. (...) Já a essa época, distintamente, o que predominava nos escritos de Furtado era uma preocupação algo diferente, qual seja, a de entender a dinâmica do processo de industrialização em pleno curso".

(11) A relevância da estrutura produtiva e do desenvolvimento tecnológico na definição do grau de desenvolvimento econômico de uma nação fica igualmente explícita na definição de subdesenvolvimento presente no trabalho. De acordo com o autor: “... podemos definir uma estrutura subdesenvolvida como aquela em que a plena utilização do capital disponível não é suficiente para a completa absorção da força de trabalho, ao nível de produtividade correspondente à tecnologia que prevalece no setor dinâmico do sistema. É a heterogeneidade tecnológica entre setores ou departamentos de uma mesma economia que caracteriza o subdesenvolvimento" (Furtado, 1961, p. 195). 
investimentos necessários para a geração de emprego e a manutenção do ritmo de expansão do produto brasileiro. De acordo com o autor:

A transformação estrutural mais importante que possivelmente ocorrerá no terceiro quartel do século XX será a redução progressiva da importância relativa do setor externo no processo de capitalização. Em outras palavras, as indústrias de bens de capital - particularmente as de equipamentos - terão de crescer com intensidade muito maior do que o conjunto do setor industrial. Essa nova modificação estrutural, que já se anuncia claramente nos anos cinqüenta, tornará possível evitar que os efeitos das flutuações na capacidade de importar se concentrem no processo de capitalização. É essa uma condição essencial para que a política econômica se permita visar o duplo objetivo de defesa do emprego e do ritmo de crescimento (Furtado, 1968, p. 247).

Ao longo de sua trajetória acadêmica, Furtado afastou-se profundamente da visão cepalina original de associação direta entre desenvolvimento e industrialização. Sem deixar de levar em conta a importância da industrialização para o crescimento do país, o autor desvincula-se da visão cepalina original, que ajudou a construir. Isto decorre da evolução do conceito de desenvolvimento presente em seus trabalhos desde a década de sessenta e que culmina no conceito de "economia industrial subdesenvolvida". Segundo Furtado:

A economia industrial subdesenvolvida não constitui uma fase que tende a ser necessariamente superada em prazo maior ou menor... Assim, desenvolvimento passa a ser definido em termos de aproximação a um paradigma que, por definição, é inalcançável, porquanto em transformação cada vez mais rápida [...] Cabe inferir, portanto, que a melhora efetiva das condições de vida da população dos países do Terceiro Mundo, particularmente dos de grande dimensão demográfica, somente seria alcançada por outros caminhos. A Índia nunca será uma Suécia de um bilhão de habitantes, nem o Brasil uma reprodução dos Estados Unidos (Furtado, 1972, p. 77 apud Szmrecsánki, 2002).

O conceito de "economia industrial subdesenvolvida" presente em Furtado (1972) explicita o afastamento do autor da associação direta entre desenvolvimento e industrialização. No entanto, é fundamental notar que a visão de que a expansão da indústria é essencial para a manutenção do ritmo de expansão da economia brasileira permanece em Furtado, em especial em função de três aspectos: 1) Os efeitos de encadeamento para frente e para trás seriam muito superiores na indústria do que nos setores primários; 2) A diminuição da pressão sobre o Balanço de Pagamentos, em função da redução da importação de produtos industriais e 3) $\mathrm{O}$ processo de inovação concentrava-se na indústria. Em outros termos, o desenvolvimento da indústria continua essencial para o crescimento econômico do país, ainda que isto não gere necessariamente um efetivo desenvolvimento da nação. 
Maria da Conceição Tavares é outra autora que contribuiu de forma decisiva para a compreensão do processo de industrialização brasileiro ${ }^{12}$. Na mesma linha de Furtado, pode-se afirmar que, embora entendendo a importância da industrialização para o crescimento do país, a autora defende que a industrialização, base da constituição das forças produtivas capitalistas, não apenas mantinha, como ampliava alguns elementos centrais do subdesenvolvimento. Este argumento é desenvolvido em seu ensaio: "Além da Estagnação", escrito em coautoria com José Serra em 1972.

Tavares e Serra (1972) demonstram a funcionalidade do processo de concentração da renda para o crescimento econômico no período do milagre econômico brasileiro, pois "enquanto o capitalismo brasileiro desenvolve-se de maneira satisfatória, a nação, a maioria da população, permanece em condições de grande privação econômica, e isso, em grande medida, devido ao dinamismo do sistema, ou, ainda, ao tipo de dinamismo que o anima" (Tavares; Serra, 1972, p. 158).

O vínculo direto estabelecido pelo pensamento da "velha Cepal" entre industrialização e desenvolvimento foi igualmente criticado por Cardoso e Faletto (1970). A análise realizada pelos autores para o caso específico do processo de substituição de importações brasileiro, seguindo a opção metodológica de "análise concreta de cada situação específica", revela os limites existentes na relação entre a industrialização e o desenvolvimento. No Brasil, claramente, há uma expansão significativa das atividades industriais, processo particularmente intenso a partir da segunda metade dos anos cinqüenta, que não se traduz automaticamente na superação do subdesenvolvimento. As relações entre países centrais e periféricos não podiam mais estar circunscritas apenas aos seus vínculos comerciais. Estas relações se davam, já na segunda metade da década de cinqüenta, entre países com diferentes graus de industrialização.

Em suma, é possível notar como em Furtado (1972), Tavares e Serra (1972) e Cardoso e Faletto (1970) a relação direta entre industrialização e desenvolvimento é negada. É importante sublinhar, no entanto, que os autores sustentam a importância da industrialização para o crescimento econômico brasileiro. O que já está claro nestas análises é que crescimento não se confunde com efetivo desenvolvimento econômico e social. É evidente que, além do esforço de análise, a evolução concreta da economia brasileira ao longo das décadas de sessenta e setenta contribuiu de forma decisiva para consolidar esta visão. No auge do "milagre econômico" já eram evidentes os limites do processo de industrialização para o desenvolvimento, sobretudo se levarmos em consideração

(12) Seu ensaio: "Auge e declínio do processo de substituição de importações no Brasil”, publicado originalmente em 1963 é internacionalmente reconhecido como fundamental na compreensão do processo de substituição de importações na América Latina. 
que a expansão da indústria deu-se concomitantemente ao aprofundamento das desigualdades regionais e a elevação no grau de concentração funcional da renda.

A visão de que o processo de industrialização era essencial para o país era compartilhada, ainda que com diferenças substantivas nas motivações e na forma de sua promoção, por diversos autores. Roberto Campos ${ }^{13}$, por exemplo, compartilhava a visão de que o processo de industrialização seria fundamental para o desenvolvimento brasileiro, pois: “(...) na grande maioria dos casos, o processo de desenvolvimento econômico não pode ser levado a bom termo sem industrialização(...) No caso brasileiro, para ser específico, parece claro que o desenvolvimento econômico deve ser associado a um industrialização intensiva" (Campos, 1953, p. 62-63 apud Bielschowsky p. 109).

Campos defendia o processo de industrialização como forma de promover o crescimento e, concomitantemente, reduzir os "pontos de estrangulamento" da economia brasileira. A existência de um mercado interno amplo e integrado e a dotação de recursos minerais eram fatores destacados pelo autor em defesa do desenvolvimento da indústria. Finalmente, defendia que países com "alto coeficiente de pressão demográfica necessitavam expandir a indústria para absorver excedentes de mão-de-obra agrícola" (Campos, 1953, p.62-63 apud Bielschowsky p. 109), ou seja, defendia a expansão industrial como forma de reduzir os níveis de desemprego do país.

É possível encontrar argumentos pró-industrialização em autores de concepção ideológica radicalmente distinta. Bielschowsky (1988) argumenta que a corrente socialista brasileira - em que se destacam as contribuições de Caio Prado Júnior e Nelson W. Sodré - pretendia viabilizar o desenvolvimento das forças produtivas capitalistas como forma de preparar o país para a passagem ao socialismo. O crescimento das atividades industriais - planificada e em bases estritamente nacionais - não seria o promotor do desenvolvimento, mas sim uma etapa necessária para alcançá-lo. A expansão destas atividades permitiria o fortalecimento do proletariado, condição fundamental para a promoção da revolução socialista.

É possível argumentar que apenas a corrente neoliberal - que contava com as contribuições de Eugênio Gudin e Octávio Gouveia de Bulhões - entendia que a estrutura produtiva deveria ser definida exclusivamente pelas forças de mercado, inexistindo qualquer vantagem para o país no desenvolvimento das atividades industriais. Em grande medida, os argumentos apresentados pela dupla GudinBulhões apenas reafirmavam os princípios liberais ricardianos presentes há muito tempo no debate.

(13) Para uma discussão detalhada dos temas na obra de Roberto Campos recomenda-se a leitura de Godoi (2007) 
Em termos de desdobramentos desta discussão, merece destaque aquilo que podemos chamar de debate sobre a "autonomia" do processo de industrialização e sua importância para o crescimento econômico. Mello (1982) é um exemplo desta discussão. $\mathrm{O}$ autor reconhece a importância da literatura crítica à visão da "velha Cepal" e entende que os benefícios da industrialização para o desenvolvimento do país foram superdimensionados. No entanto, em sua análise, os investimentos realizados no final da década de sessenta, particularmente na produção de insumos industriais e de bens de capital, finalizaram o processo de industrialização brasileiro. A partir deste momento, os limites para a expansão do setor industrial encontravam-se vinculados, segundo o autor, à sua capacidade endógena de acumulação de capital.

Para o autor, a capacidade de acumulação do setor industrial se constituía, desde sua fase "restringida", no elemento central para a determinação do ritmo de crescimento econômico do país. Na realidade, em sua visão, só se pode falar em industrialização no Brasil, ainda que restringida, a partir de 1933, ano em que o crescimento do produto passa a ser predominantemente determinado pelo ritmo de expansão das atividades industriais. Com a "industrialização pesada", a partir dos investimentos associados ao Plano de Metas em 1956, "a autodeterminação do capital estava, doravante, assegurada" o que definia o potencial de crescimento da economia. Assim, se a Cepal superdimensionou a importância da industrialização para o desenvolvimento, também parece verdadeiro argumentar que Mello (1982) cometeu o mesmo equívoco no que tange a capacidade "endógena" de expansão das atividades industriais e sua capacidade de promover o crescimento.

O debate acadêmico que relativiza o papel da industrialização no desenvolvimento foi simplesmente ignorado nos gabinetes dos governos militares. A opção brasileira ao choque do petróleo de 1973, sintetizada no segundo Plano Nacional de Desenvolvimento (II PND), torna evidente, para os formuladores do plano, a relação existente entre o processo de industrialização e a superação do subdesenvolvimento. Realizar os investimentos necessários para "completar" a matriz produtiva industrial era o passo central para superar as restrições ao crescimento do país e transformar o Brasil numa potencial mundial, afinal de contas a partir deste processo "O Brasil poderia validamente aspirar ao desenvolvimento e à grandeza” (II PND apud Lessa, 1998, p. 17).

Em relação ao debate sobre o processo de industrialização na segunda metade da década de setenta, especialmente sobre a estratégia do II PND, deve-se destacar a contribuição ao tema de Castro e Souza (1985). Os autores argumentam que o II PND foi responsável por uma profunda mudança qualitativa da estrutura produtiva brasileira. A instalação e/ou ampliação da capacidade produtiva em setores da indústria de base, particularmente na produção de insumos industriais, se constituía num passo essencial para o desenvolvimento. Em especial, destacam 
Castro \& Souza (1985), os grandes projetos industriais dos II PND seriam responsáveis por uma redução estrutural do coeficiente de importação. Ao discutir o II PND, afirmam os autores: "Trata-se de um plano (O II PND) cujas propostas centrais encontram-se profundamente marcadas pela consciência de que o mundo se encontrava mergulhado em grave crise, que tornou patente a vulnerabilidade da economia brasileira. Mas o plano encontra-se também impregnado da decisão de levar a termo o processo de desenvolvimento econômico" (Castro; Souza, 1985, p. 45 , grifo meu)

A queda estrutural do coeficiente de importação permitiria à economia brasileira galgar uma trajetória de crescimento com restrições externas mais brandas. O megasuperávit comercial obtido em 1984 - ano em que se verificou a expansão do nível de atividade - se constituiria numa forte evidência empírica da mudança estrutural do coeficiente de importantes. Este processo não se constituía num mero ajuste às condições adversas impostas pelo II Choque do Petróleo. Além do ajuste conjuntural, o II PND encontrava-se "impregnado da decisão de levar a termo o processo de desenvolvimento econômico", em mais uma clara associação entre industrialização e desenvolvimento.

Em síntese, o esforço empreendido pela Cepal no final da década de quarenta e início dos anos cinqüenta em dar sustentação teórica a importância do processo de industrialização para o desenvolvimento econômico da América Latina foi, sem espaço para dúvidas, um dos pilares do debate econômico brasileiro. $\mathrm{O}$ abandono da relação direta entre industrialização e desenvolvimento proposto, entre outros, por Furtado (1972), Tavares e Serra (1972) e Cardoso e Faletto (1970), não significou a negação de que a manutenção da industrialização era condição essencial para a expansão do produto doméstico, ainda que isto não significasse necessariamente desenvolvimento econômico.

\section{0 debate nos anos 90: abertura, estabilidade e a "questão tecnológica"}

O debate sobre a relação entre a estrutura produtiva e o desenvolvimento nos anos 90 foi profundamente marcado, no plano interno, pelo início do processo de abertura comercial e a conseqüente ampliação da competição no mercado local e pela estabilidade de preços promovida a partir da implantação do Plano Real. No plano externo, o acirramento do processo de globalização e as profundas transformações tecnológicas processadas no final da década de setenta e início dos anos oitenta jogaram um papel relevante na configuração do debate.

O mito da industrialização como promotora direta do desenvolvimento já tinha sido abandonado há muito tempo. Da mesma forma, a ideia de que dada a instalação dos setores de bens de produção, "a industrialização chegara ao fim e a autodeterminação do capital estava, doravante, assegurada” (Mello, 1982, p. 122), também perdia força dado o contexto de profundas e aceleradas transformações da 
estrutura produtiva, fruto da mudança de paradigma tecnológico. Neste cenário, a discussão mudou de foco. O papel exercido pelos setores dinâmicos deste novo paradigma para a competitividade externa e para o crescimento econômico de longo prazo foi alvo de uma série de análises.

O debate foi profundamente marcado pelo crescimento da capacidade competitiva do Japão e dos novos países industrializações da Ásia, com destaque para o exemplo da Coréia do Sul. Os bons resultados obtidos por estes países durante as décadas de setenta e oitenta foram apontados como evidências de que os investimentos em desenvolvimento e aprendizado tecnológico em setores industriais dinâmicos do paradigma tecnológico de base microeletrônica se constituíam em elementos centrais para a retomada do crescimento econômico de longo prazo.

As comparações entre o modelo coreano e brasileiro foram extensamente realizadas. Canuto (1994) é um bom exemplo dos trabalhos nesta área. Ao promover a comparação entre o processo de industrialização dos dois países, o autor destaca o foco do modelo coreano, voltado para o mercado externo, no ganhos de competitividade através da realização de pesados investimentos em pesquisa, desenvolvimento e aprendizado tecnológico associados à instalação de ramos dinâmicos do novo paradigma tecnológico. Por sua vez, o modelo brasileiro voltado para o mercado interno e focado, na segunda metade da década de setenta, na instalação da indústria de base caracterizou-se pelo reduzido esforço de desenvolvimento de inovações e de instalação destes novos setores. Em grande medida, as distintas trajetórias seguidas pelas economias selecionadas são explicadas pelas diferenças existentes na estratégia de industrialização.

Coutinho (1994), em prefácio do livro de Canuto (1994), vai além, advogando pela existência de uma relação direta entre a opção coreana de industrialização e seu processo de desenvolvimento econômico.

A vizinhança benigna - a proximidade física e econômica do Japão - explica em boa medida o sucesso sul coreano. Mas não é só: houve competência por parte do Estado e da grande empresa privada para aproveitar, com méritos próprios, as oportunidades de ingressar diretamente na Terceira Revolução Industrial. Isso singulariza a experiência da Coréia do Sul - o único caso de industrialização tardia e periférica em condições de saltar para o restrito clube dos países avançados (Coutinho, 1994, p. 10).

Do ponto de vista da evolução das ideias, é evidente a associação das concepções de Coutinho (1994) e Canuto (1994) com a visão, consolidada no modelo cepalino da década de cinqüenta, de que a estrutura produtiva é um elemento fundamental para a trajetória de crescimento de uma nação. Da mesma forma, é notória a influência do pensamento neoschumpeteriano e o resgate do tema da inovação na concepção dos autores. 
O impacto da abertura comercial sobre a estrutura produtiva, em especial sobre a indústria, ocupou um espaço de destaque na discussão. Pólos antagônicos formaram-se neste momento: de um lado, argumentava-se que a abertura comercial promoveria uma brutal desestruturação do parque industrial brasileiro, com efeitos nocivos para o processo de desenvolvimento; de outro, defendia-se enfaticamente que o processo de abertura em curso promoveria uma correção nos rumos do desenvolvimento do país, eliminando os excessos industrializantes promovidos durante o período clássico da industrialização via substituição de importações.

Bielschowsky e Stumpo (1996) discutem os efeitos iniciais do processo de abertura comercial para o Brasil. Em linhas gerais, concluem que economia brasileira, ao menos até a implantação do Plano de Real e a valorização da moeda, reagiu de forma positiva aos estímulos promovidos pelos primeiros anos da abertura, sobretudo quando comparada à promovida por outros países latinoamericanos, como por exemplo, a Argentina.

A estrutura industrial brasileira, do ponto de vista da composição da produção, manteve-se praticamente inalterada nos primeiros anos da abertura, situação oposta à verificada pela indústria argentina, que registrou uma importante retração no valor gerado pelos setores mais dinâmicos ${ }^{14}$. Há, claramente, uma análise qualitativa deste processo. $\mathrm{Na}$ visão dos autores, o estilo argentino de restruturação pode ser considerado como de "dessofisticação através de importações" (Bielschowsky; Stumpo, 1996, p. 181), com efeitos negativos para o desenvolvimento no longo prazo. A capacidade de sustentação de ramos dinâmicos da indústria, com destaque para os setores de metalmecânica e eletrônica, é entendida como um elemento positivo do caso brasileiro, numa clara associação entre desenvolvimento e sustentação da estrutura produtiva industrial.

A combinação da abertura comercial com o processo de valorização da moeda a partir a implantação do Real em julho de 1994 modificou o cenário de forma significativa, com perda rápida de competitividade, sobretudo dos setores industriais intensivos em tecnologia. A reversão do saldo da balança comercial após a implantação do Plano e o crescimento significativo das importações de bens industriais intensivos em tecnologia se constituía em evidencias deste cenário de deterioração das condições de competitividade. Bielschowsky e Stumpo (1996), preocupados com esta situação, defendem que existe uma "conveniência de inaugurar uma política de competitividade industrial” (p. 189), tendo em vista que “competitividade industrial, saúde da balança de pagamentos, e estabilidade de

(14) A participação dos setores de metalmecânica e eletroeletrônica na composição da indústria manufatureira passou de 31,5\% em 1980 para 32,5\% em 1994. No caso Argentino, entre 1977 e 1992, observa-se uma redução na participação destes setores mais dinâmicos de 30,6\% para 25,8\% do valor gerado pela indústria, com redução significativa da participação de equipamentos e bens de consumo durável (exceto material de transporte) 
preços são questões que, a longo prazo, estão irremediavelmente associadas" (p. 193). Coutinho (1996) segue linha bastante similar. De acordo com o autor:

Infelizmente, os condicionantes de ordem conjuntural tendem a agravar as fragilidades estruturais na medida em que não permitem a formação de um horizonte de desenvolvimento sustentado. Este panorama realista das atuais condições do Brasil em face da globalização não constitui, porém, uma fatalidade imutável. O Brasil possui energias e potencialidades para optar por outra rota. O programa de estabilização pode ser reorientado para assentar-se em um novo eixo de desenvolvimento estabilizador. Reformas podem ser empreendidas e as vulnerabilidades podem ser reduzidas com um projeto de desenvolvimento industrial (Coutinho, 1996, p. 237, grifo meu).

Em síntese, Bielschowsky e Stumpo (1996) e Coutinho (1996) são exemplos da literatura que observam, com preocupação, os movimentos da estrutura produtiva brasileira após a implantação do Plano Real e a combinação de valorização da moeda com abertura comercial. Defendem abertamente o uso de instrumentos de política industrial, com intuito de minorar os impactos da elevação da competitividade, sobretudo da parcela devida ao contexto conjuntural de valorização da moeda, nos setores industriais, particularmente na indústria intensiva em tecnologia e geradora de alto valor agregado.

Os anos noventa assistiram, também, a profusão de uma série de trabalhos que entendem que o modelo de substituição de importações, base para a expansão das atividades industriais, foi o principal responsável pelo frágil desenvolvimento econômico do país. Ainda que diretamente vinculadas, é possível avaliar duas dimensões presentes nestas discussões: uma teórica e outra focada no processo histórico de expansão da indústria no "modelo" de substituição de importações. No plano teórico, é evidente a associação desta literatura com a visão ricardiana de vantagens comparativas e os consagrados modelos tradicionais de comércio internacional à la Heckscher-Ohlin e a defesa de um padrão de especialização centrado na exploração de fatores produtivos abundantes.

Ao discutir o efeito da abertura comercial sobre a estrutura produtiva, Moreira e Correa (1997, p.88) advogam que: "Em termos da composição do produto industrial, o saldo parece ter sido positivo, muito embora existam algumas interrogações. Do ponto de vista estático, o aumento da participação dos setores intensivos em recursos naturais indica um melhor aproveitamento de um recurso que o país tem em abundância".

Há também, conforme mencionado acima, uma crítica ao modelo específico de industrialização brasileiro, genericamente denominado por esta literatura de "substituição de importações (SI)". O foco da crítica a SI encontra-se em dois elementos: 1) baixo ritmo de crescimento da produtividade total dos fatores e 2) a utilização da inflação como mecanismo de "financiamento" do 
modelo. Em relação ao primeiro elemento, destacam-se a elevada proteção externa concedida à indústria nacional e o crescimento excessivo do número de setores que só se sustentavam graças a esta proteção ${ }^{15}$, como determinantes importantes para o frágil desenvolvimento da produtividade dos fatores.

Em relação ao tema da inflação, esta literatura, como apresentado, por exemplo, por Franco (1998) defende que o crescimento inflacionário do Estado constituiu-se num dos elementos chaves do "padrão de financiamento" do modelo de substituição de importações. No contexto de baixo nível de poupança doméstica, o Estado em seu ímpeto industrializante, promoveu, em diversos momentos, o financiamento de seus investimentos via ampliação dos déficits públicos, financiados por emissão monetária, com efeitos diretos sobre a inflação. A associação entre o modelo industrializante, a inflação e a tragédia social brasileira é direta, como pode ser observado na passagem abaixo:

Várias gerações de desenvolvimentistas", inclusive através dessa designação autoconferida, ocuparam-se basicamente de exaltar as chaves mágicas da industrialização, mas sempre mantendo prudente distância dos custos de um crescimento meio enviesado, dependente de uma apropriação indébita, vale dizer, do financiamento inflacionário do Estado. A tragédia social de nossos dias não é fenômeno recente, e surpreendentemente jamais foi associada ao inflacionismo, tão íntimo de nosso desenvolvimento por tantos anos (Franco, 2005, p. 259).

Em síntese, é possível notar profundas alterações no debate acadêmico brasileiro na década de noventa sobre o tema do papel da industrialização no desenvolvimento. Moreira \& Correia (1997) e Franco (1998) são apenas dois exemplos de uma extensa literatura que de um lado recupera os elementos essenciais do modelo de vantagens comparativas ricardiano, e de outro promove uma dura crítica ao modelo brasileiro de industrialização via "substituição de importações" e seus efeitos deletérios sobre a evolução da produtividade e da inflação no país. Por sua vez, resiste uma concepção, ainda que marginal, de defesa da promoção de políticas industriais focadas na expansão dos setores dinâmicos do novo paradigma tecnológico, como proposto, entre outros, por Canuto (1994) e Coutinho $(1994,1996)$.

\section{Desindustrialização e a escolha da "política industrial": o debate recente sobre a estrutura produtiva e o desenvolvimento}

Os debates recentes sobre o papel da estrutura produtiva no desenvolvimento são influenciados pelo cenário econômico. A redução da participação do setor industrial no PIB brasileiro é um dos elementos que anima

(15) “A industrialização por substituição de importações promoveu um número excessivo de setores, à revelia dos recursos disponíveis no país, e promoveu estruturas de mercado ineficientes que só se sustentavam graças à proteção elevada" (Moreira; Correa, 1997, p. 88). 
este debate. Esta redução, que seria em si importante para o tema, torna-se ainda mais relevante quando o processo ocorre, ao menos nos anos mais recentes, concomitantemente a uma valorização real do padrão monetário. Até que ponto a redução da participação da indústria no produto é um processo natural ou é, ao menos em parte, decorrente da perda de competitividade associada à valorização do câmbio? Quais os impactos desta redução da participação da indústria para o desenvolvimento econômico no longo prazo? Estas são questões recorrentes do debate econômico que se preocupa com o tema da estrutura produtiva e que, como proposto, surgem das condições econômica vigentes. $\mathrm{Na}$ seqüência passamos a analisar como, a partir da observação destes debates, é possível, ainda que indiretamente, notar qual o papel atribuído a estrutura produtiva para $o$ desenvolvimento ${ }^{16}$.

As discussões sobre a "desindustrialização" e seu vínculo com a ocorrência de um processo de "doença holandesa" no país têm sido extensamente exploradas pela literatura de cunho "heterodoxo". Oreiro e Feijó (2010), por exemplo, discutem o tema a partir do estabelecimento de uma diferenciação entre os conceitos. A partir das evidências empíricas disponíveis e de uma revisão da literatura econômica - com destaque para os trabalhos de Marquetti (2002) e Feijó et AL. (2005) - os autores afirmam que existem "evidências conclusivas a respeito da ocorrência de desindustrialização na economia brasileira para o período 19861998" (Oreiro; Feijó, 2010, p. 231). Em função de mudanças metodológicas procedidas pelo IBGE em 2007, a mesma afirmação não pode ser feita para o período posterior a alteração do regime de câmbio em 1999. Por fim, outra conclusão importante do artigo é que existem: "sinais inquietantes da ocorrência de "doença holandesa", ou seja, de desindustrialização causada pela apreciação da taxa real de câmbio que resulta da valorização dos preços das commodities e dos recursos naturais no mercado internacional" (Oreiro; Feijó, 2010, p. 231) ${ }^{17}$.

No entanto, dado o objetivo específico deste trabalho, é mais importante destacar a conexão, proposta por Oreiro e Feijó (2010), entre a estrutura produtiva e o desenvolvimento. De acordo com estes autores, "os economistas heterodoxos acreditam que a indústria é o motor do crescimento de longo prazo das economias capitalistas" (Oreiro; Feijó, 2010, p.223). Há, portanto, uma associação direta entre indústria e crescimento de longo prazo, sintetizada na passagem abaixo:

(16) É importante destacar que o foco da seção não é o debate da desindustrialização ou da opção da política industrial, mas sim observar, a partir destas discussões, qual o papel atribuído à estrutura produtiva no processo de desenvolvimento.

19 Uma visão distinta é encontrada em Nassif (2008). As evidências selecionadas pelo autor apontam para a inexistência de um processo de "desindustrialização" no Brasil, particularmente no período recente. 
Em suma, a indústria é vista como "especial" pelo pensamento heterodoxo, pois ela é a fonte de retornos crescentes de escala (indispensável para a sustentação do crescimento no longo-prazo), é a fonte e/ou a principal difusora do progresso tecnológico e permite o relaxamento da restrição externa ao crescimento de longo prazo... Nesse contexto, a desindustrialização é um fenômeno que tem impacto negativo sobre o potencial de crescimento de longo-prazo, pois reduz a geração de retornos crescentes, diminui o ritmo de progresso técnico e aumenta a restrição externa ao crescimento (Oreiro; Feijó, 2010, p. 231).

Uma linha de raciocínio similar é encontrada em por Bresser-Pereira (2010). Ao discutir o que é o "novo desenvolvimentismo", o autor enfatiza a importância da definição de uma "estratégia nacional de crescimento" na qual a expansão das atividades industriais, sobretudo de alta tecnologia, joga um papel fundamental para o crescimento econômico no longo prazo.

De fato, o debate sobre a ocorrência de um processo de desindustrialização só tem importância se, de uma perspectiva teórica, a estrutura produtiva for um elemento relevante para a trajetória de desenvolvimento. Da mesma forma, as discussões sobre a política industrial ganham relevância e importância na medida em que apresentam em sua formulação a visão sobre o papel da estrutura produtiva industrial no desenvolvimento.

Diversas são as formas de agrupar o debate recente sobre política industrial no país. No entanto, em função dos objetivos do artigo, pode-se propor uma organização deste debate em dois grupos: 1) Os que defendem que a promoção de políticas industriais deve ser pensada como um elemento de transformação da estrutura produtiva, o que, via de regra, implica adotar políticas de corte setorial; e 2) Os que defendem que a promoção de políticas industriais setoriais só faz sentido econômico na presença de "falhas de mercado". Não é de se estranhar que como tomam pontos de partida distintos, os resultados em termos de sugestão de política industrial sejam igualmente distintos.

Como exemplos da primeira linha, apresentam-se, entre outros, Kupfer (2003) e Suzigan e Furtado (2006). Na segunda linha apresentam-se, entre outros, Ferreira e Hamdan (2003) e Pinheiro et al. (2007). Kupfer (2003) é enfático em demonstrar o papel central da execução de políticas industriais como forma de "transformação" da estrutura produtiva e promoção do desenvolvimento:

Desenvolvimento econômico é mais do que crescimento do nível de produto. Não é, e em economias atrasadas, não pode ser mais do mesmo. Desenvolvimento é crescimento com mudança estrutural. É nessa perspectiva que a política industrial deve ser pensada. Cabe à política industrial acelerar os processos de transformação produtiva que as forças de mercado podem 
operar, mas o fazem com lentidão, e disparar os processos que estas mesmas forças são incapazes de articular (Kupfer, 2003, p. 281).

Há, portanto, em Kufper (2003) uma defesa da política industrial como forma de transformação da estrutura produtiva, necessária para o desenvolvimento econômico. Esta política deve agir de forma complementar às forças de mercado, mas também disparar "os processos que estas mesmas forças são incapazes de articular". Esta forma de conceber a política industrial, no qual o Estado deve desempenhar um papel ativo no desenvolvimento de setores específicos, não faz sentido de uma perspectiva mais convencional, tal como a apresentada em Ferreira \& Hamdan (2003). Uma passagem dos autores, ao comentar a proposta de Kupfer (2003) deixa evidente este ponto:

Quanto às diretrizes da política industrial no plano setorial, a proposta de incentivos a setores não competitivos nos parece totalmente descabida. Ao invés de alocarmos recursos para setores que hoje não são competitivos internacionalmente... deveríamos nos questionar porque não deveríamos nos especializar mais intensamente (mas não exclusivamente) na produção daquilo em que somos eficientes, ou seja, em setores intensivos em trabalho não qualificado e recursos naturais. Não há nada de inerentemente "nobre" ou "plebeu" neste tipo de especialização. Isto somente reflete o fato de sermos eficientes hoje na produção de determinados bens e serviços e de que o custo-benefício aqui é bem menor que o das alternativas dinâmicas (Ferreira; Hamdan, 2003, p. 313).

Qualquer semelhança com as indicações de Ricardo para o padrão especialização entre Portugal e Inglaterra, apresentada na epígrafe deste artigo, não nos parece ser mera coincidência. Ao defender a especialização na produção baseada na dotação de fatores existente hoje na economia, Ferreira e Hamdan (2003) promovem uma defesa explícita das vantagens comparativas ricardianas e da literatura de comércio internacional à la Heckscher-Ohlin e a defesa de um padrão de especialização centrado na exploração de fatores produtivos abundantes hoje, o que elimina da discussão o caráter de transformação da estrutura produtiva, ponto de partida, entre outros, de Kupfer (2003).

Em síntese, a discussão recente sobre a escolha da política industrial evidencia as diferenças existentes na literatura brasileira sobre o papel da indústria para o desenvolvimento brasileiro.

\section{Considerações Finais}

Este artigo buscou promover uma revisão sobre o papel do processo de industrialização para o desenvolvimento econômico brasileiro ${ }^{18}$. Trata-se de um

(18) Para um tratamento sintético do tema, com apresentação dos elementos básicos da discussão, preparou-se um quadro resumo, apresentado em anexo. 
tema controverso, com idas e vindas, sem vencedores ou vencidos. Não há também, como não há em uma ciência social, nenhum sentido evolutivo. Pelo contrário, o que fica patente na revisão - ainda que reconhecidamente limitada - é que os argumentos do passado continuam vivos no debate acadêmico mais recente. Impossível não notar as "semelhanças" existentes entre a proposta de especialização produtiva apresentada em Ferreira e Hamdan (2003) e a ideia de vantagens comparativas ricardianas; assim como é inegável que a defesa do desenvolvimento industrial como forma de permitir um "relaxamento da restrição externa ao crescimento de longo prazo" presente em Oreiro e Feijó (2010) já se encontrava há muito tempo presente no debate.

Ao final desta revisão, conclui-se que dois momentos analisados merecem um destaque. O primeiro é o desenvolvimento das ideias cepalinas originais ${ }^{19}$, no imediato pós-Guerra. Em Prebisch (1949) e na Cepal (1951) há um modelo teórico refinado de análise do funcionamento do sistema econômico que permite defender de forma mais consistente - em relação aos debates até então realizados - o projeto industrializante. Hoje, parece relativamente evidente que o pensamento cepalino original pecou pelo excesso de importância atribuída à industrialização para a superação do subdesenvolvimento. Isto não deve retirar o brilho desta construção e sua capacidade de apresentar, de uma forma consistente, argumentos favoráveis à industrialização e que até hoje se encontram presentes no debate acadêmico.

O segundo momento que merece destaque é a virada dos anos noventa e a retomada do "pensamento liberal". Neste período, apesar da resistência de alguns autores na defesa da tese de que o desenvolvimento dos setores tecnologicamente avançados era fundamental para o crescimento econômico, as teses que defendiam um padrão de especialização produtiva em setores intensivos em trabalho não qualificado e recursos naturais ganharam força no país. Ganharam força, também, as teses de que o processo de abertura comercial promoveria uma "limpeza" na estrutura produtiva, expurgando do sistema econômico os setores industriais artificialmente criados sob a égide do "modelo de substituição de importações".

Por fim, os debates mais recentes, particularmente a discussão sobre a escolha e a pertinência de políticas industriais, evidenciam a existência de uma clara divisão entre o que poderíamos chamar de "herdeiros do pensamento cepalino e de sua revisão crítica" e os "herdeiros do pensamento clássico ricardiano". Para os primeiros, a defesa da industrialização como um dos elementos relevantes para o desenvolvimento justifica-se, ao longo do tempo por uma série de fatores, dentre os quais destacamos: 1) Os bens industriais permitem maior geração/agregação de valor, comparativamente aos produtos primários; 2) Os encadeamentos produtivos

(19) Isto não significa, como argumenta Fonseca (2000), que a originalidade desta discussão possa ser atribuída à Cepal. Boa parte das discussões atribuídas ao pensamento cepalino já estavam presentes no debate há muito tempo. 
para frente e para trás da indústria são superiores aos de outras atividades, sobretudo quando comparados com as atividades primárias; 3) A inovação tecnológica acontece preponderantemente, ainda que não de forma exclusiva, nos setores industriais; 4) É fonte de "retornos crescentes de escala, indispensável para a sustentação do crescimento no longo-prazo"; e 5) As atividades industriais, por conta das características de elasticidade-preço e elasticidade-renda de sua demanda, são essenciais para as condições de crescimento com equilíbrio do Balanço de Pagamentos.

Para os "herdeiros do pensamento clássico ricardiano" o que importa em última instância é que a especialização produtiva seja, em sua essência, norteada pela exploração de fatores produtivos abundantes, o que no caso brasileiro implica na utilização intensiva de trabalho não qualificado e recursos naturais.

$\mathrm{Na}$ introdução do artigo, apresentou-se como questão central de investigação a seguinte indagação: quais os fundamentos para a controvérsia existente sobre o papel da industrialização no desenvolvimento econômico brasileiro? É o momento de respondê-la. Embora o artigo tenha utilizado os termos "debate" e "discussão" todo o tempo, deve-se reconhecer que a uso destes termos deve ser feito com ressalvas. As diferenças metodológicas existentes entre os interlocutores são de tal magnitude que a possibilidade de ocorrência de um diálogo, necessário para que se tenha de fato um debate, é, na melhor das hipóteses, limitada. De um lado, os "herdeiros do pensamento cepalino" partem da hipótese de que as atividades industriais possuem vantagens intrínsecas que justicam a sua defesa negando, portanto, a priori o desenvolvimento de um raciocínio à la vantagens comparativas. De outro lado, os "herdeiros do pensamento clássico ricardiano" encontram-se hermeticamente fechados na defesa das vantagens comparativas e do caráter atemporal dos ganhos associados a um padrão de especialização produtiva que use intensivamente os recursos abundantes.

Em tempos em que os economistas têm respostas para todas as questões e para todos os interlocutores, este breve artigo chega ao fim de forma relativamente distinta. Ao invés de respostas, prefere deixar algumas indagações. Os argumentos apresentados pela literatura que defende a importância da indústria para o desenvolvimento são válidos para as condições vigentes na economia mundial hoje e no futuro? Certamente é preciso explorar esta indagação numa agenda de pesquisa que fortaleça as evidências empíricas e teóricas sobre o tema. O mundo mudou profundamente nos últimos anos, mas boa parte dos argumentos desta literatura remontam ao período pós II Guerra Mundial.

Por seu turno, cabem também diversas indagações aos "herdeiros do pensamento clássico ricardiano". Há experiência concreta de uma nação com as particularidades de dimensão territorial e populacional do Brasil que tenha se 
desenvolvido efetivamente sem promover, em algum grau, o desenvolvimento das atividades industriais? A estratégia de promover a especialização em setores intensivos em mão de obra não qualificada e/ou recursos naturais é um caminho de fato viável para o desenvolvimento brasileiro, levando-se em consideração, entre outros elementos, a dimensão populacional e a sua profunda heterogeneidade?

As respostas a estas questões encontram-se muito além dos objetivos deste trabalho. Constituem-se, na realidade, em agendas amplas de pesquisa que, se desenvolvidas, contribuiriam para o debate sobre o papel da industrialização no desenvolvimento econômico brasileiro.

\section{Referências Bibliográficas}

ABREU, M. P. Os funding loans brasileiros - 1898-1931. Pesquisa e Planejamento Econômico (PPE), v. 32, n. 3, dez. 2002.

BIELCHOWSKY, R. Pensamento econômico brasileiro: o ciclo ideológico do desenvolvimentismo. Rio de Janeiro: Ipea/Inpes, 1988. (Série PNPE, n. 19).

Maria da Conceição Tavares. Revista de Economia Contemporânea, Rio de Janeiro, v. 14, n. 1, 2010.

; SUTMPO, G. A Internacionalização da indústria brasileira: números e reflexões

depois de alguns anos de abertura. In: BAUMANN, R. (Org.). O Brasil e a economia global. Rio de Janeiro: Elsevier, 1996.

BRESSER-PEREIRA, L. C. Globalization and competition: why some emergent countries succeed while others fall behind. Cambridge University Press, 2010.

CAMPOS, R. A crise econômica brasileira. Digesto Econômico, São Paulo, nov. 1953.

CANUTO, O. Brasil e Coréia do Sul: Os (des) caminhos da industrialização tardia. São Paulo: Nobel, 1994.

CARDOSO, F. H.; FALETTO, E. Dependência e desenvolvimento da América Latina. Rio de Janeiro: Zahar, 1970.

Dos governos militares a Prudente - Campos Sales. In: O BRASIL Republicano. São Paulo: Difel, 1975.

CARONE, E. O pensamento industrial no Brasil (1880-1945). Rio de Janeiro/São Paulo: Difel, 1977.

CASTRO, A. B.; SOUZA, F. E. P. A economia brasileira em marcha forçada. Rio de Janeiro: Paz e Terra, 1985.

A capacidade de crescer como problema. In: REIS VELLOSO, João Paulo. $O$

Real, o crescimento e as reformas. Rio de Janeiro: José Olimpyo Editora, 1996. 
CEPAL. Economic survey of Latin America, 1949. Santiago, Chile, 1949. (E/CN.12/ rev.1).

COUTINHO, L. Prefácio. In: CANUTO, O. Brasil e Coréia do Sul: os (des) caminhos da industrialização tardia. São Paulo: Nobel, 1994.

A fragilidade do Brasil em face da globalização. In: BAUMANN, R. (Org.). O Brasil e a economia global. Rio de Janeiro: Elsevier, 1996.

; FERRAZ, J. C. Estudo da Competitividade da Indústria Brasileira. 3. ed. Campinas: Editora da Unicamp/Papirus, 1995.

FEIJÓ, C. A.; CARVALHO, P. G.; ALMEIDA, J. S. G. Ocorreu uma desindustrialização no Brasil?. São Paulo: IEDI, nov. 2005. Mimeo.

FERREIRA, P. C.; HAMDAN, G. Política industrial no Brasil: ineficaz e regressiva. Econômica, v. 5, n. 2, 2003.

FIORI, J. L. O cosmopolitismo de cócoras. Estudos Avançados, v. 14, n. 39, maio/ago. 2000 .

FONSECA, P. C. D. As origens e as vertentes formadoras do pensamento cepalino. Revista Brasileira de Economia, Rio de Janeiro, v. 54, n. 3, jul./set. 2000.

. Gênese e precursores do desenvolvimentismo no Brasil. Pesquisa \& Debate, v. 15 , n. 2 (26), 2004.

FRANCO, G. H. B. A primeira década republicana. In: ABREU, M. P. (Org.). A ordem do progresso. Rio de Janeiro: Campus, 1989.

. Inserção externa e o desenvolvimento. Revista de Economia Política, v. 18, n. 3, jul./set. 1998.

Auge e declínio do inflacionismo no Brasil. In: GIAMBIAGI, G.; VILLELA, A.; CASTRO, L. B.; HERMANN, J. (Org.). Economia Brasileira Contemporânea (19452004). Rio de Janeiro: Campus Elsevier, 2005.

FURTADO, C. Desenvolvimento e subdesenvolvimento. Rio de Janeiro: Fundo de Cultura, 1961.

. Formação econômica do Brasil. 8. ed. São Paulo: Companhia Editora Nacional,

1968.

1972.

Análise do "modelo” brasileiro. Rio de Janeiro: Ed. Civilização Brasileira,

GODOI, B. B. C. A influência de Roberto Campos na economia brasileira. Dissertação (Mestrado)-Programa de Pós-Graduação em História Econômica da Universidade de São Paulo (USP), 2007.

GOLDENSTEIN, L. Repensando a dependência. Rio de Janeiro: Paz \& Terra, 1994. 
GUDIN, E. Rumos de política econômica. Relatório apresentado para a Comissão de Planejamento Econômico (1945). In: SIMONSEN, R.; GUDIN, E. A controvérsia do planejamento na economia brasileira. 3. ed. Ipea, 2010.

KUPFER, D. Política industrial. Econômica, v. 5, n. 2, dez. 2003.

LESSA, C. A estratégia de desenvolvimento 1974-1976: sonho e fracasso. 2. ed. Campinas: Unicamp. Instituto de Economia, 1998. (Série: “30 Anos de Economia UNICAMP").

LUZ, N. V. A luta pela industrialização do Brasil. 2. ed. São Paulo: Alfa-ômega, 1975.

MANTEGA, G. A economia política brasileira. São Paulo: Polis; Petrópolis: Vozes, 1984.

MARQUETTI, A. Progresso técnico, distribuição e crescimento na economia brasileira: 1955-1998. Estudos Econômicos, v. 32, n. 1, 2002.

MELlO, J. M. C. O capitalismo tardio. São Paulo, Brasiliense, 1982.

MOREIRA, M. M.; CORREA, P. G. Abertura comercial e indústria: o que se pode esperar e o que se vem obtendo. Revista de Economia Política, v. 17, n. 2 (66), abr.jun. 1997.

NASSIF, A. Há evidências de desindustrialização no Brasil? Revista de Economia Política, São Paulo, v. 28, n. 1, jan./mar. 2008.

OREIRO, J. L.; FEIJÓ, C. A. Desindustrialização: conceituação, causas, efeitos e o caso brasileiro. Revista de Economia Política, v. 30, n. 2, abr. 2010.

PERISSINOTTO, R. M. Classe dominante e política econômica na economia cafeeira (1906-1930). Perspectivas, São Paulo, v. 16, p. 165-189, 1993.

Classes dominantes e hegemonia na República Velha. Campinas: Editora da Unicamp, 1994

PINHEIRO, M. C.; FERREIRA, P. C.; PESSÔA, S. A.; SCHYMURA, L. G. Por que o Brasil na precisa de política industrial. Ensaios Econômicos. EPGE/FGV, mar. 2007.

POSSAS, M. L. Multinacionais e industrialização no Brasil. In: BELLUZO, L. G. M.; COUTINHO, R. Desenvolvimento capitalista no Brasil: ensaios sobre a crise. 2. ed. São Paulo, Brasiliense, 1983.

PREBISCH, R. The economic development of Latin America and its principal problems. Economic Commission for Latin America (Document E/CN 12.89), 1949.

RICARDO, D. On the principles of political economy and taxation. 3rd ed.. London: John Murray, Albermale Street, 1821. Disponível em: www.books.google.com. Acesso em: 10 jun. 2011.

SIMONSEN, R. A planificação da economia brasileira. Parecer apresentado ao Conselho Nacional de Política Industrial (1944). In: SIMONSEN, R.; GUDIN, E. A controvérsia do planejamento na economia brasileira. 3. ed. Ipea, 2010. 
SUZIGAN, W, FURTADO, J. Política industrial e desenvolvimento. Revista de Economia Política, v. 26, 2006.

SZMRECSÁNKI, T. Celso Furtado e o início da industrialização no Brasil. Revista de Economia Política, v. 22, n. 2 (86), abr./jun. 2002.

TAVARES, M. C. Auge e declínio do processo de substituição de importações no Brasil. In: Da substituição de importações ao capitalismo financeiro. Rio de Janeiro: Zahar, 1972. ; SERRA, J. Além da estagnação. In: Da substituição de importações ao capitalismo financeiro. Rio de Janeiro: Zahar, 1972. 